\title{
COMPARATIVE ANALYSIS OF PUBERTAL GROWTH SPURT PREDICTORS - MARTINS AND SAKIMA METHOD AND GRAVE AND BROWN METHOD
}

\author{
ANÁLISE COMPARATIVA DOS ESTIMADORES DO SURTO DE CRESCIMENTO \\ PUBERAL - MÉTODOS DE MARTINS E SAKIMA E GRAVE E BROWN
}

Karina Emy IGUMA, Orivaldo TAVANO², Izabel Maria Marchi de CARVALHO ${ }^{3}$

1- DDS, B.Sc., Graduate Student of the Specialization Course in Radiology of the Craniofacial Anomalies Rehabilitation Hospital (HRAC), University of São Paulo.

2- DDS. MSc, PhD, Assistant Professor, Coordinator of the Post-Graduation Course in Dental Radiology, São Leopoldo Mandic University. 3- DDS. MSc, PhD, Assistant Professor, Coordinator of the Course in Dental Radiology, HRAC-University of São Paulo.

Corresponding address: Izabel Maria Marchi de Carvalho - Hospital de Reabilitação de Anomalias CranioFaciais de Bauru-USP Departamento de Radiologia - R. Silvio Marchione, 3-20. - Caixa Postal 150 - 17043-900 - Bauru - SP - Brasil - Telefone: (14) 3235-8079 E-mail: karinaemy@hotmail.com - izamarchi@uol.com.br

Received: May 10, 2004 - Modification: August 23, 2004 - Accepted: December 12, 2004

\begin{abstract}
T aim of this study was to evaluate whether Martins and Sakima and Grave and Brown methods are useful for the study of pubertal growth spurt in children with cleft lip and palate. A total of 132 hand-wrist radiographs of patients from HRAC/USP aged 7 to 17 years old were analyzed, including girls and boys. Six radiographs of each age and gender were employed. These methods were applied to evaluating the stages of the hand-wrist ossification and epiphyseal formation, by graphic representation. The Martins and Sakima and the Grave and Brown methods revealed that the initial, peak and final stages of pubertal growth spurt occurred between 9 to 10,12 and 15 years old, respectively, in the female gender. Similarly, in the male gender, both Martins and Sakima and Grave and Brown methods showed similar mean ages: 12, 14 and 16 years old for initial, peak and final stages of pubertal growth spurt, respectively. The Pearson's correlation test showed high and significant correlation $(r=0.99$ and $p<0.001)$ between the methods investigated. In conclusion, the methods appeared to be highly and significantly correlated as regards the analysis of children with cleft lip and palate. Moreover, based on the literature and present results, it is possible to suggest that the two methods have shown similar pattern and may be used with equal efficiency for assessment of the pubertal growth spurt in children with cleft lip and palate.

Uniterms: Bone age measurement, growth; Bone age measurement, development; Hand-wrist radiograph.
\end{abstract}

\section{RESUMO}

$O$

objetivo deste trabalho foi avaliar se os métodos de Martins e Sakima e Grave e Brown são aplicáveis para o estudo do surto de crescimento puberal (SCP) de crianças com fissuras lábio-palatais. Foram analisadas 132 radiografias carpais de pacientes do HRAC-USP, dos gêneros masculino e feminino, com a faixa etária de 7 a 17 anos, utilizando 6 radiografias de cada idade e gênero. Ambos os métodos estudam os estágios de ossificação dos ossos da mão e punho e os estágios que se encontram as epífises, através de gráficos. Com relação a este estudo, no gênero feminino, tanto para Martins e Sakima quanto para Grave e Brown, o início, pico e final do SCP ocorreram entre 9 e 10 anos, 12 anos e 15 anos, respectivamente. Da mesma forma, para o gênero masculino, Martins e Sakima e Grave e Brown mostraram médias de idade similares: 12, 14 e 16 anos para início, pico e final do SCP, respectivamente. O teste de correlação de Pearson mostrou uma alta e significativa correlação $(\mathrm{r}=$ 0,99 e $\mathrm{P}<0,001$ ) entre os métodos estudados. Em conclusão, esses dois métodos de avaliação do surto de crescimento e desenvolvimento apresentaram uma alta correlação quando aplicados na avaliação de crianças com fissuras lábio-palatais. Baseando-se na literatura e nos resultados dessa pesquisa, é possível sugerir que ambos os métodos podem ser aplicados nos pacientes com fissuras lábio-palatais para a obtenção do surto de crescimento puberal.

Unitermos: Idade óssea, crescimento; Idade óssea, desenvolvimento; Radiografia carpal. 


\section{INTRODUCTION}

The human being presents inherent features of development, which last about 20 years and encompass periods of acceleration and deceleration. There are two periods of acceleration during the long human growth phase20. The first is called childhood growth spurt and occurs at 6 or 7 years old, whereas the second occurs during adolescence and is called pubertal growth spurt (PGS) $)^{5,6,14}$.

The bone or skeletal age is the indicator most commonly employed in studies on growth and development and it is regarded as a reliable record of biological development ${ }^{9}$. The establishment of bone age is based on the skeletal changes during the development and it may be evaluated in certain areas of the body, in all growth stages ${ }^{2,10,18}$. Physiological, biochemical and anatomical phenomena influence the growth and development and these are affected by ethnic, environmental, metabolic, nutritional, sexual, hormonal and genetic factors ${ }^{1,2}$.

Studies have been conducted in an attempt to achieve the best indicator of the degree of bone maturity. The current tendency is the utilization of hand-wrist radiographs for that purpose $\mathrm{e}^{3,5,6,7,14,15}$.

Identifying the PGS stage is important because it may allow the evaluation of growth in height of the child and consequently of the potential facial growth, which is useful in orthodontic treatment planning ${ }^{12,20}$.

Many methods are indicated for the establishment of bone age using the hand bones. The analysis of Martins and Sakima ${ }^{14}$ is based on the stage of carpal ossification and it is related to the peak pubertal height growth according to a graph, describing each ossification stage of the hand and wrist bones, the epiphyseal stages and compares them to the growth stage.

Grave and Brown ${ }^{6}$ employed a method, which the bone maturation stage of an individual in relation to the peak pubertal height growth is separately analyzed for boys and girls on a graph comprising two growth curves, one for each gender, by fourteen stages of hand-wrist ossification pooled in two categories: ossification of individual bones and epiphyseal changes.

The pubertal growth spurt (PGS) occurs in all persons but is different from individual to individual as to its period of initiation, intensity and duration ${ }^{1,2}$. This demonstrates that the chronological age is not a reliable data to evaluate the bone maturation process. Therefore, the bone age is more valued as the method that best represents this maturation ${ }^{17}$.

The aim of this study was to evaluate whether the Martins and Sakima ${ }^{14}$ and Grave and Brown ${ }^{6}$ methods may be applied for assessment of the pubertal growth spurt in children with cleft lip and palate.

\section{MATERIALS AND METHODS}

A total of 132 hand-wrist radiographs of patients with cleft lip and palate attending the Craniofacial Anomalies
Rehabilitation Hospital - USP, Bauru, SP, Brazil, were analyzed. The sample comprised 66 males and 66 females aged 7 to 17 years old, and six radiographs of each age and gender were employed. The individuals were included in this study regardless of race, socioeconomic background, weight and/or height of the patients and type of cleft.

The left hand was selected for achievement of the handwrist radiograph, which was kept in contact on the film, with the long axis of the middle finger aligning the long axis of the forearm, the fingers not together and the thumb at an approximately $30^{\circ}$ angle with the forefinger. The X-ray tube was centralized on the third metacarpus.

The 132 hand-wrist radiographs were analyzed and compared by the Martins and Sakima ${ }^{14}$ and Grave and Brown ${ }^{6}$ methods.

The results were submitted to the Pearson correlation test at a significance level of $1 \%$. The data was displayed in graphs and table.

\section{RESULTS}

The correlations between the Martins and Sakima ${ }^{14}$ and Grave and Brown ${ }^{6}$ methods are displayed in Table 1 and Figures 1 and 2.

\section{DISCUSSION}

There was no significant difference between the average ages for patients with cleft lip and palate compared to the average reported in the literature for patients without clefts, according to the Martins and Sakima ${ }^{14}$ and Grave and Brown ${ }^{6}$ methods.

Figure 1 was prepared based on Table 1 to demonstrate the mean figures estimated by the PGS, on which the simultaneous evolution of bone age and chronological age is observed for both methods. These graphs also demonstrate that the girls displayed an earlier development than the boys, and thus the chronological age is lower compared to the ossification stages for the same event of PGs. The overall development is similar in both genders, except for the fact that the ossification events occur earlier in girls.

The dispersion graph in Figure 2 reveals a small difference in the growth rate between 15 and 17 years old when the Martins and Sakima ${ }^{14}$ and Grave and Brown ${ }^{6}$ methods are compared in both genders, because the Martins and Sakima ${ }^{14}$ method encompasses more stages than the Grave and Brown ${ }^{6}$ method.

The prediction figures of PGS according to the chronological age for both methods follow a linear growth tendency, with similar outcomes in all stages.

The results achieved by the Pearson correlation coefficient were as follows: 0.95 for comparison between the Martins and Sakima ${ }^{14}$ method and chronological age; 0.96 for comparison between the Grave and Brown ${ }^{6}$ method and chronological age; and 0.99 for comparison between 
the Martins and Sakima ${ }^{14}$ and Grave and Brown ${ }^{6}$ methods.

Concerning the female gender, the results of the present study demonstrated that the PGS was initiated between 9 and 10 years of age and the peak PGS occurred at 12 years of age according to both Martins and Sakima ${ }^{14}$ and Grave and Brown ${ }^{6}$ methods. Similar findings were reported by other authors $^{6,11,13,16,20}$. In the present study, the PGS was completed at 15 years of age. Differently, Moraes ${ }^{16}$ observed that this stage occurred at 12 and a half, Martins et al. ${ }^{13}$ and $\mathrm{Ursi}^{20}$ reported that it happened at 13 years old. Corroborating the present findings, Elgoyhen ${ }^{4}$ described that the interval from the onset and completion of PGS was 9 to 14 years old, compared to 10 to 14 years old according to Hägg and Taranger ${ }^{8}$.

As regards the male gender, the PGS was found to initiate at 12 years of age with the peak PGS at 14 years of age, according to both the Martins and Sakima ${ }^{14}$ and Grave and Brown $^{6}$ methods. Similar outcomes were found by Moraes ${ }^{16}$,
Lima and Vigorito ${ }^{11}$, Tibério and Vigorito ${ }^{19}$, Martins, et al. ${ }^{13}$, $\mathrm{Ursi}^{20}$, and Grave and Brown ${ }^{6}$. Completion of the PGS in the present study was observed at 16 years old. On the other hand, Moraes ${ }^{16}$, Martins, et al. ${ }^{13}$ and $\mathrm{Ursi}^{20}$ reported that the final PGS occurred at 15 years old. Similarly, Elgoyhen ${ }^{4}$ observed that the interval between the onset and completion of PGS was 12 and a half to 15 years old, in agreement with the study of Hägg and Taranger ${ }^{8}$, which found that such interval occurred from 12 to 17 years old.

The present study observed that the ossification events occurred 2 to 3 years earlier in girls compared to boys. This data is in agreement with Mercadante ${ }^{15}$ and $\mathrm{Ursi}^{20}$.

Association between skeletal maturation and PGS in the present study may be observed in Figure 1, which reveals the increase in chronological age according to the evolution of the PGS stages. Therefore, the ossification events of the hand and wrist may be employed by the orthodontist to evaluate the growth activity of a child ${ }^{6,14,15}$.

TABLE 1- Mean figures of the pubertal growth spurt stages by the Martins and Sakima ${ }^{17}$ and Grave and Brown ${ }^{6}$ methods.

\begin{tabular}{lcccc}
\hline Age & $\begin{array}{c}\text { Martins and Sakima } \\
\text { method - ossification } \\
\text { stages - } \\
\text { Female Gender }\end{array}$ & $\begin{array}{c}\text { Martins and Sakima } \\
\text { method - ossification } \\
\text { stages - } \\
\text { Male Gender }\end{array}$ & $\begin{array}{c}\text { Grave and Brown } \\
\text { method - ossification } \\
\text { stages - } \\
\text { Female Gender }\end{array}$ & $\begin{array}{c}\text { Grave and Brown } \\
\text { method - ossification } \\
\text { stages - }\end{array}$ \\
\hline 7 & 0.2 & 0 & 0.2 & 0 \\
Male Gender \\
8 & 1.7 & 0.6 & 1.7 & 0.5 \\
9 & 3.2 & 1.7 & 3.2 & 1.6 \\
10 & 4.3 & 2.8 & 4.3 & 2.8 \\
11 & 5.3 & 4 & 5.3 & 4 \\
12 & 7.5 & 4.3 & 7.5 & 4.3 \\
13 & 9.2 & 6.8 & 9.2 & 6.8 \\
14 & 11 & 7.7 & 10.8 & 7.7 \\
15 & 14.3 & 9.7 & 12.7 & 9.7 \\
17 & 16 & 13.2 & 14 & 12.3 \\
\hline
\end{tabular}

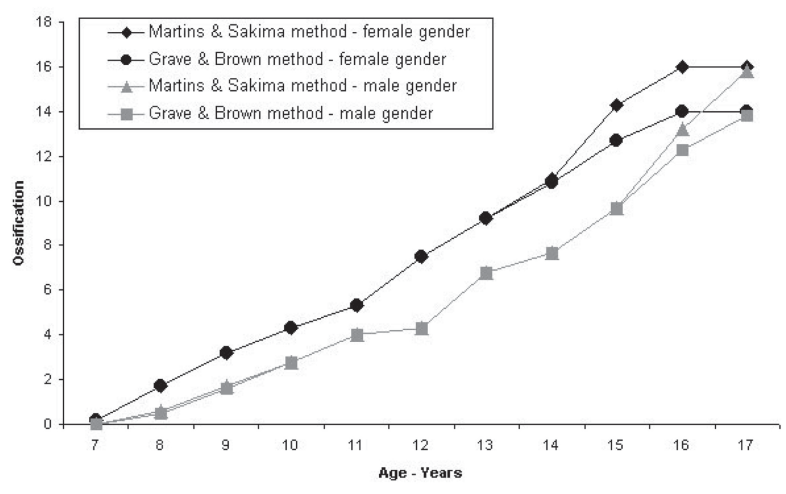

FIGURE 1- Graphic representation of the mean results of pubertal growth spurt prediction by the Martins and Sakima ${ }^{14}$ and the Grave and Brown ${ }^{6}$ method, applied to children with cleft lip and palate aged 7 and 17 years old

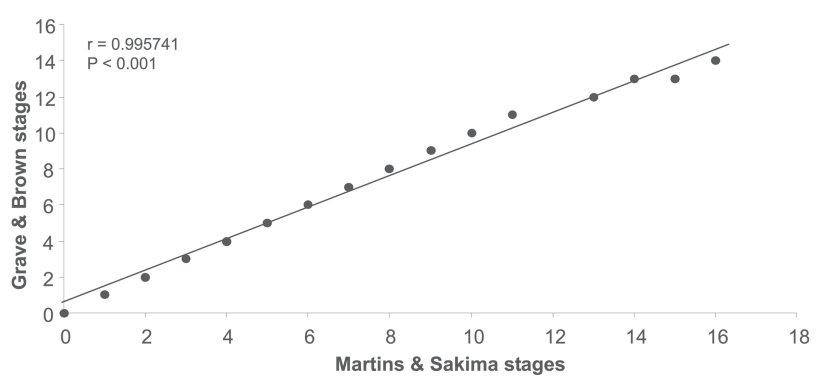

FIGURE 2- Graphic representation of the correlation between the puberal growth spurt predictions of Martins ${ }^{14}$ and Grave and Brown ${ }^{6}$, for children with cleft lip and palate aged 7 to 17 years old 


\section{CONCLUSIONS}

Both methods of growth assessment employed presented high and significant similarities $(r=0.99$ and $\mathrm{P}<0.01)$ in the evaluation of children with cleft lip and palate. The literature reviewed and the present results suggest that both methods may be applied to patients with cleft lip and palate for achievement of the pubertal growth spurt.

The female gender of the study sample demonstrated to grow faster than the male gender, according to both methods investigated.

The only discrepancy between both methods studied for evaluation of the pubertal growth spurt occured at the ages 15,16 and 17 years old.

\section{REFERENCES}

1- Camarote EA, Kushinski FB. Estudo das correlações entre altura corporal e dimensões crânio-faciais, em crianças brasileiras. Rev Inst Ciênc Saúde 1997;(n.esp.):59-65.

2- Damante JH. Influência de alguns eventos pubertários sobre determinados parâmetros de avaliação da idade biológica, em meninas brancas, brasileiras, da região de Bauru. Bauru; 1978. [Tese de Doutorado - Faculdade de Odontologia da USP].

3- Eklöf O, Ringertz H. A method for assessment of skeletal maturity. Ann Radiol 1967;10:330-6.

4- Elgoyhen JC. Crescimento facial e seu interesse em ortodontia. In: Interland S., ed. Ortodontia: bases para a iniciação. 3.ed. São Paulo: Artes Médicas; 1994. p.105-14.

5- Fishman LS. Radiographic evaluation of skeletal maturation: a clinically oriented method base don hand-wrist films. Angle Orthod 1982;52:88-112.

6- Grave KC, Brown T. Skeletal ossification and the adolescent growth spurt. Am J Orthod 1976;69:611-9.

7- Greulich WW, Pyle SI. Radiographic atlas of skeletal development of the hand and wrist. Stanford: Stanford University Press; 1959.

8- Hägg U, Taranger J. Skeletal stages of the hand and wrist as indicators of the pubertal growth spurt. Acta Odontol Scand 1980;38:187-200.

9- Haiter Neto F, Tavano O. Análise comparativa da estimativa da idade óssea pelo índice de Eklöf e Ringertz com a idade cronológica pelos métodos manual e computadorizado. Ortodontia 1997;30:318.

10- Leite HR, O’Reilly MT, Close JM. Skeletal age assessment using the first, second, and third fingers of the hand. Am J Orthod Dentofacial Orthop 1987; 92:492-8.

11- Lima SM, Vigorito JW. Avaliação da idade esquelética de crianças brasileiras leucodermas, de 08 a 15 anos, em relação a ossificação do osso sesamóide da junção metacarpo-falangeal do dedo polegar. Ortodontia 1989; 22:14-25.

12- Marshall D. Radiographic correlation of hand, wrist and tooth development. Dent Radiogr Photogr 1976; 49:51-74.

13- Martins JCR, Sakima T, Uetanabaro T Iniciação à cefalometria radiológica. Araraquara: UNESP; 1983.

14- Martins JCR, Sakima T. Considerações sobre a previsão do surto de crescimento puberal. Ortodontia 1977;10:164-70.
15- Mercadante MMN. Radiografia de mão e punho. In: Ferreira FV. Ortodontia: diagnóstico e planejamento clínico. Porto Alegre: Artes Médicas; 2002. p.189-223.

16- Moraes MEL. Surto de crescimento puberal. Relação entre mineralização dentária, idade cronológica, idade dentária e idade óssea - Método radiográfico. São José dos Campos, 1997. [Tese de Doutorado - Faculdade de Odontologia da UNESP].

17- Prates NS. Tendências de crescimento da face. Rev Gaúcha Odontol 1982; 30:130-5.

18- Tavano O. Estudo das principais tabelas de avaliação da idade biológica, através do desenvolvimento ósseo, visando sua aplicação em brasileiros leucodermas da região de Bauru. Bauru; 1976. [Tese de Doutorado - Faculdade de Odontologia de Bauru da USP].

19- Tibério S, Vigorito JW. O estudo da maturação esquelética de crianças brasileiras leucodermas, de 08 a 15 anos, em referência à ossificação dos ossos pisiforme, ganchoso, falanges média e proximal dos dedos 2 e 3. Ortodontia 1989;22:4-19.

20- Ursi WJS. Determinação da maturidade esquelética através de radiografias carpais: sua importância no tratamento ortodônticoortopédico. In: Interlandi S. Ortodontia: bases para a iniciação. 4.ed. São Paulo: Artes Médicas; 1999. p.377-92. 